\title{
POLA PENYIMPANGAN MUSLIM \\ TERHADAP AJARAN AGAMANYA \\ ( Perspektif Pendidikan Islam)
}

\author{
Muhammad Muhtar Arifin Sholeh ${ }^{1}$
}

\begin{abstract}
Muslims in Indonesia and all over the world have the guidance regarding moral, which is clearly mentioned in the Quran and Sunnah (the prophet tradition). They have the written value, which is directly or indirectly used as a guidance. Nevertheless, the reality shows that those great values are not always done and realized in the real life of society. Religious and cultural teaching is only as a cognitive consumption (as knowledge), no realization, so that affective and psychomotor aspects are ignored.

Behaviour of society which is far from the believed values will deviate from religious teaching. The paper discusses the problems of why Muslims deviate from their religious teaching, and of what factors which affect the deviation.

The deviation done by Muslims are as follows; they do not understand their religious teaching, do not pray, do not fast in Ramadhan month, do not pay zakat, do not wear Islamic cloth. The factors affecting deviation of religious teaching are personality factor (laziness, no interest, no action), economy factor (poverty, work hard, money oriented), academic (knowledge) factor (no study, no understanding), and environmental factor (relation to family, neighbour, friends, and society).
\end{abstract}

Keywords: Moslem, Deviation, Islamic Teaching

\section{ABSTRAK}

Umat Islam di Indonesia, sebagaimana sesamanya yang ada di belahan bumi yang lain memiliki panduan tentang akhlak yang secara jelas tertuang dalam Al Quran dan Shunnah. Mereka memiliki nilai-nilai tertulis yang secara langsung dan tidak langsung menjadi panduan Walaupun demikian, realitas menunjukkan bahwa nilai-nilai luhur tersebut tidak selalu dihayati dan diamalkan dalam kehidupan sehari-hari di masyarakat. Ajaran agama dan budaya hanya sebatas untuk konsumsi kognisi (pengetahuan), tidak untuk diamalkan, sehingga aspek afeksi dan psikomotor terabaikan.

Perilaku masyarakat yang berjarak dengan nilai-nilai yang diyakininya semacam itu tentu menimbulkan penyimpangan dalam pelaksanaan ajaran agama. Tulisan ini akan membhas hasil pengamatan atas sejumlah permasalahan

Dosen Program Studi Pendidikan Agama Islam (PAI) Jurusan Tarbiyah Fakultas Agama Islam (FAI) Universitas Islam Sultan Agung (UNISSULA) Semarang 
antara lain sebagai berikut: (1) Mengapa terjadi penyimpangan ? (2) Faktor apa saja yang berkaitan dengan berbagai penyimpangan tersebut?

Penyimpangan-penyimpangan yang muncul pada diri seorang muslim antara lain adalah tidak memahami agama Islam, tidak shalat, tidak puasa, tidak membayar zakat, tidak berbusana Islami. Faktor-faktor yang berkaitan dengan berbagai penyimpangan agama adalah faktor kepribadian (malas, tidak berminat, tidak mengamalkan), faktor ekonomi (kemiskinan, sibuk bekerja, orientasi pada uang dan harta), dan faktor keilmuan (tidak belajar, tidak mengetahui, dan tidak paham), dan faktor lingkungan (hubungan dengan keluarga, tetangga, teman, dan masyarakat umumnya).

Kata kunci : muslim, penyimpangan, pengajaran Islam

\section{A. PENDAHULUAN}

"Penculik Yulianti Tertangkap", "Truk Tronton yang Dibajak Ditinggal di SPBU Jenarsari”, "Guru Bantu Tersangka Penimbun BBM", (Suara Merdeka, 25 September 2005), "17 Penyidik Polri Diperiksa: Kasus Pembobolan BNI", "Polda Periksa Empat Kontraktor: Dugaan Kasus Ingub Kabupaten Tegal", "Dua Orok Kembar Ditemukan di Sampah" (Suara Merdeka, 30 September 2005), "Tembak Sopir, Rampok Rp. 200 Juta" ; "Pencuri Uang BI Dituntut Enam Bulan Penjara"; "Sindikat Pengutil Diringkus"; "Ratusan VCD Bajakan Disita" ; "Komplotan Pencuri Komputer Dibekuk" ; "Lima Perampok Koperasi Tertangkap" ; "Perampok Satroni Rumah Pengusaha Hotel" ; "Miras dan VCD Porno Dimusnahkan"; "Indo Rizky Kemalingan" (Suara Merdeka, 22 Juli 2003). "Buntut Kasus Pemerkosaan di Solo: Dibongkar, Sindikat Penjual gadis" ; "Sering Mengganggu, Tewas Dibantai" ; "Kakek Cabul Dihukum 4 tahun"; " 2 PNS Dipergoki Selingkuh" ; "Tilep Uang Desa, Dibekuk Polisi, BPD Skors Kades Tulas" (Kedaulatan Rakyat, 30 Juli 2003).

Beberapa ilustrasi di atas menunjukkan bahwa dalam kenyataan di Indonesia masih terdapat banyak kaum deviant (orang yang menyimpang dari aturan atau hukum), baik kalangan pejabat atau rakyat. Penyimpangan tersebut dapat berwujud perampokan, pencurian, perjudian, pembunuhan, pengeboman, pembajakan, pemerkosaan, penyalahgunaan obat (narkoba), prostitusi, korupsi, kolusi, nepotisme, dan sebagainya. Setiap hari surat kabar tidak pernah absen memberitakan berita-berita kriminal, bahkan terdapat surat kabar dan program televisi yang secara khusus mengulas berita kriminal.

Para pendiri (founding father) negara Indonesia telah menetapkan, sebagaimana dituangkan dalam Pembukaan UUD 1945, bahwa dasar negara adalah Pancasila yang mencakup sila ketuhanan, kemanusiaan, persatuan, permusyawaratan-perwakilan, dan sila keadilan sosial. Pancasila mengandung nilai-nilai luhur yang harus dijunjung tinggi, dihayati, dan diamalkan oleh 
seluruh warga bangsa Indonesia dalam kehidupan sehari-hari di masyarakat, agar menjadi manusia Indonesia seutuhnya.

Nilai-nilai luhur yang harus dijunjung tinggi tersebut adalah, misalnya, bertaqwa kepada Tuhan yang Maha Esa, taat menjalankan ajaran agama masing-masing, saling mencintai sesama manusia, menjunjung tinggi nilai-nilai kemanusiaan, mencintai tanah air dan bangsa, rela berkurban untuk tanah air dan bangsa, mengutamakan musyawarah untuk kepentingan bersama, bersikap adil, menghargai karya orang lain, dan sebagainya. Nilainilai luhur tersebut bersumber dari ajaran agama dan budaya yang berada di masyarakat.

Walaupun demikian, realitas menunjukkan bahwa nilai-nilai luhur tersebut tidak selalu dihayati dan diamalkan dalam kehidupan sehari-hari di masyarakat. Ajaran agama dan budaya hanya sebatas untuk konsumsi kognisi (pengetahuan), tidak untuk diamalkan, sehingga aspek afeksi dan psikomotor terabaikan. Kajian mendalam tentang ajaran agama dan budaya menjadi hal yang sangat penting. Pendidikan budi pekerti dalam kebudayaan Jawa dan pendidikan akhlaq dalam agama Islam menjadi hal yang sangat esensial untuk dipahami, dihayati, dan diamalkan. Hal ini mengingat bahwa kebudayaan Jawa menjadi budaya yang dominan di Indonesia dan agama Islam menjadi agama yang dipeluk oleh mayoritas warga Indonesia.

\section{B. RUMUSAN MASALAH}

Masyarakat Indonesia dikenal sebagai masyarakat religius, berketuhanan yang maha esa, ramah, sopan, serta menjunjung tinggi nilainilai budaya, tetapi mengapa masih banyak dari mereka, termasuk para pejabat, melakukan penyimpangan seperti perampokan, pencurian, perjudian, pembunuhan, pembajakan, pengeboman, prostitusi, korupsi, dan sebagainya. Mengapa terjadi penyimpangan ? Faktor apa saja yang berkaitan dengan berbagai penyimpangan tersebut?

\section{TINJAUAN PUSTAKA}

\section{Mencari Ilmu menurut Islam}

Dalam pandangan Islam mencari ilmu adalah wajib, baik bagi muslimin maupun muslimat. Dalam hadits riwayat Bukhori Muslim dikatakan, "mencari ilmu itu fardhu (wajib) bagi setiap muslim laki-laki maupun perempuan". Ilmu yang wajib dituntut terutama adalah ilmu agama, yaitu ilmu tentang pokok-pokok pengetahuan Islam seperti rukun Islam, rukun iman, kemampuan membaca dan memahami al-Quran dan al-Hadits, dan sebagainya. Sedangkan ilmu-ilmu lain sifatnya hanya sunnah. Menurut Imam Ghazali, ilmu agama itu bersifat fardhu ain (wajib pribadi), sedangkan ilmu lainnya bersifat fardhu kifayah (wajib kelompok). 


\section{Solidaritas Sosial dalam Islam}

Agama Islam, melalui ajaran-ajarannya, sangat menganjurkan hidup sosial, yaitu hidup dengan berhubungan, berkomunikasi, bekerja sama dan membantu orang lain, terutama orang yang lebih lemah. Dalam suatu hadits disebutkan bahwa ciri-ciri orang yang beriman kepada Allah dan hari akhir adalah menghormati tamu, menghormati tetangga (rukun dengan tetangga), dan berbicara yang baik (jika tidak bias lebih baik diam).

Dalam suatu hadits lain, yang diriwayatkan oleh Bukhori Muslim, dinyatakan bahwa Rasulullah saw menyuruh untuk mengamalkan tujuh perkara : (1). menjenguk orang sakit; (2). mengantarkan jenazah; (3). mendoakan orang bersih; (4). menolong/membantu orang yang lemah; (5). menolong/membantu orang yang teraniaya, (6). menyebarkan salam; dan (7). melaksanakan sumpah. Dalam hadits lain yang juga diriwayatkan oleh Bukhori Muslim disebutkan bahwa hak seorang muslim terhadap muslim lainnya ada lima, yaitu menjawab salam, menjenguk orang sakit, mengantar jenazah, mendatangi undangan, dan mendoakan orang yang bersin.

\section{Perintah Busana Islami}

Islam mewajibkan pemeluknya baik laki-laki maupun perempuan untuk berbusana islami, yaitu berbusana menurut tuntutan agama Islam dengan prinsip menutup aurat (bagian tubuh yang harus tertutup), kesopanan, dan keindahan. Aurat laki-laki adalah antara pusar dan lutut, tetapi busana islami untuk laki-laki harus tetap sopan. Sedangkan aurat perempuan adalah seluruh anggota tubuh kecuali wajah dan telapak tangan, sehingga seorang wanita muslimah harus memakai baju panjang, bawahan panjang, dan berkerudung jika keluar rumah. Dalam al-Quran Allah berfirman :

"Hai Nabi, katakanlah kepada isteri-isterimu, anak-anak perempuanmu dan isteriisteri orang mukmin: "Hendaklah mereka mengulurkan jilbabnya ke seluruh tubuh mereka." Yang demikian itu supaya mereka lebih mudah untuk dikenal, karena itu mereka tidak diganggu. Dan Allah adalah Maha Pengampun lagi Maha Penyayang". (QS. Al-Ahzaab, 33:59).

\section{Larangan-larangan Kemaksiatan}

Agama Islam melarang berbagai kemaksiatan. Hal ini diatur dalam banyak ayat dalam Al Qur'an. Larangan tersebut antara lain seperti berjudi, perzinaan (QS. 5: 91; 17: 32), mabuk-mabukkan (QS. 5:90-91), mencuri (QS. 5: 38), merampok, membunuh, dan sebagainya. 


\section{M E T O D E P E N E L I T I A N}

\section{Lokasi Penelitian}

Lokasi penelitian meliputi kota Solo, Yogya, dan Semarang. Lokasi tersebut dipilih berdasar asumsi bahwa daerah tersebut merupakan daerah di mana mayoritas penduduknya muslim.

\section{Jenis Penelitian}

Penelitian ini merupakan penelitian lapangan (field research) yang didukung dengan penelitian literatur (library research). Dari segi data dan analisisnya, penelitian ini lebih merupakan penelitian kualitatif (qualitative research), tetapi dalam batas tertentu hal-hal yang bersifat kuantitatif juga diperlukan.

\section{Jenis dan Sumber Data}

Data penelitian bersifat (berjenis) kualitatif dan kuantitatif (dalam batas tertentu). Data kualitatif ialah yang fakta-fakta yang menunjukkan tingkat mutu seperti nilai-nilai agama dan budaya. Data kuantitatif adalah fakta-fakta yang menunjukkan tingkat jumlah seperti jumlah penduduk, prosentase, dan sebagainya. Data penelitian juga bersifat primer (data dari sumber/orang pertama) dan sekunder (data dari sumber/orang kedua atau ketiga). Data bersumber dari literatur (buku, jurnal, majalah, surat kabar), berbagai websites di internet, dan dari lapangan (responden, informan, tempat/lokasi, dokumen).

\section{Identifikasi Subyek Penelitian (responden, informan)}

Subyek penelitian yang dimaksud adalah responden dan informan, baik laki-laki maupun perempuan. Responden adalah orang yang memberi respon terhadap pertanyaan-pertanyaan yang diberikan. Responden dalam penelitian ini ialah orang-orang Muslim yang diminta menjawab pertanyaan - pertanyaan dalam angket. Dalam penelitian ini, sekitar 200 buah angket didistribusikan di tiga kota, yaitu 100 angket di Semarang, 50 angket di Solo, dan 50 angket di Yogyakarta. Namun demikian, jumlah semua angket yang dikembalikan sebanyak 143 angket, terdiri dari 77 angket di Semarang, 35 angket di Solo, dan 31 angket di Yogyakarta, yang selengkapnya dalam tabel berikut :

Tabel 2 : Jumlah Angket yang Disebar dan Kembali

\begin{tabular}{|c|c|c|c|c|}
\hline No. & Nama Kota & Angket Disebar & Angket Kembali & \% Kembali \\
\hline 1 & Semarang & 100 buah & 77 buah & $77 \%$ \\
\hline 2 & Yogyakart & 50 buah & 31 buah & $62 \%$ \\
\hline 3 & Solo & 50 buah & 35 buah & $70 \%$ \\
\hline & J u m 1 a h & 200 buah & 143 buah & $71,5 \%$ \\
\hline
\end{tabular}


Informan ialah orang yang memberi informasi, yaitu tokoh masyarakat Jawa dan orang-orang muslim Jawa yang diminta menjawab pertanyaanpertanyaan dalam wawancara mendalam (depth interview). Dalam penelitian ini, 16 orang telah diwawancarai sebagai informan, yang selengkapnya terdapat dalam tabel berikut :

Tabel 3 : Daftar Nama - nama Informan

\begin{tabular}{|c|l|l|l|}
\hline No. & \multicolumn{1}{|c|}{ Nama Informan } & \multicolumn{1}{|c|}{ Pekerjaan } & \multicolumn{1}{c|}{ A s a l } \\
\hline 1 & Etik Kurniawati & G u r u & Semarang \\
\hline 2 & Imam Subandi & Pensiunan (Tokoh Masyarakat) & Semarang \\
\hline 3 & S u p r i y a n t o & Sopir angkot & Semarang \\
\hline 4 & T e g u h & Tukang sablon & Semarang \\
\hline 5 & Mukhlis & Tukang cukur & Semarang \\
\hline 6 & Suci Wulansari & G u r u & Semarang \\
\hline 7 & S a m i n e m & Penjual es dorong & Yogyakarta \\
\hline 8 & Sriyanto (Bapak \& Ibu) & Penjual sate & Yogyakarta \\
\hline 9 & Yanto Suwito & Sopir becak & Yogyakarta \\
\hline 10 & Wito Utomo & Sopir becak & Yogyakarta \\
\hline 11 & Yuliana Nazli N S & G u r u & Yogyakarta \\
\hline 12 & M Abdul Aziz & Karyawan lepas penerbit & Yogyakarta \\
\hline 13 & Heru B. Irlambang & G u r u & Yogyakarta \\
\hline 14 & Piping Prihantari. & G u r u & Yogyakarta \\
\hline 15 & Hadi Sutrisno & Sopir becak & S o l o \\
\hline 16 & S a m i j a n & Sopir becak & S o l o \\
\hline
\end{tabular}

\section{Metode Pengumpulan Data}

Metode pengumpulan data dalam penelitian ini adalah angket, wawancara, observasi, dan dokumentasi.

\section{a. Angket (questionaire)}

Angket penelitian ini berisi tentang motif-motif (penyebab) tindakan menyimpang, tujuan tindakan menyimpang, pemahaman tentang pendidikan akhlaq dalam agama Islam, pengamalan pendidikan budi pekerti dan akhlaq tersebut, dan sebagainya. Angket diberikan kepada orang-orang Muslim yang dipilih sebagai responden. Khusus dalam agama Islam dalam angket ditanyakan tentang pengetahuan agama, shalat, puasa, zakat, al-Quran, dan busana Islami.

\section{b. Wawancara (interview)}

Wawancara dilakukan secara mendalam (depth interview) dengan orang-orang Muslim. Wawancara ini berisi tentang pendidikan budi pekerti dalam kebudayaan Jawa, pendidikan akhlaq dalam agama Islam, pengamalan pendidikan budi pekerti dan akhlaq tersebut, alasan penyimpangan sosial yang terjadi, dampak penyimpangan, dan solusi terhadap penyimpangan tersebut. Khusus dalam agama Islam ditanyakan tentang shalat, puasa, zakat, al-Quran, dan busana Islami. 


\section{c. Observasi (observation)}

Observasi adalah proses pengamatan di lapangan penelitian. Dalam hal ini, pengamatan dilakukan terhadap realitas sosial di masyarakat Jawa, seperti dalam hal penyimpangan yang dilakukan, dampak penyimpangan tersebut, dan bagaimana mereka mengamalkan ajaran budi pekerti dan akhlaq.

\section{E. METODE ANALISA DATA}

Metode analisa data dalam penelitian ini ialah terutama analisa kualitatif, sedangkan analisa kuantitatif diperlukan dalam batas tertentu.

\section{Analisa Kualitatif}

Analisa kualitatif dilakukan dengan mendeskripsi informasi atau fakta sosial yang ada, kemudian menganalisisnya dengan cara memahami secara mendalam, menghubung-hubungkan konsep atau teori satu dengan lainnya, mengklasifikasi dalam kriteria tertentu, menjelaskan klasifikasi, menghubungkan antar klasifikasi tersebut, mengevaluasinya, dan akhirnya menyimpulkannya.

\section{Analisa Kuantitatif}

Analisa kuantitatif adalah analisa terhadap angka-angka yang diperoleh dari data penelitian. Bentuk analisa kuantitatif tersebut adalah angka prosentase dan angka jumlah. Angka-angka tersebut diperoleh dari dokumen-dokumen, literatur, para responden ataupun informan.

\section{F. HASIL DAN PEMBAHASAN}

\section{Data Penyimpangan terhadap Agama Islam}

\section{a. Pengetahuan tentang Agama Islam}

Bagi seorang muslim, mencari ilmu adalah wajib, terutama ilmu agama. Belajar ilmu agama Islam merupakan keharusan bagi seorang muslim, merupakan wajib a'in (kewajiban individu). Adapun para responden mempelajari ilmu agama Islam dari berbagai sumber, sebagaimana tercantum dalam tabel berikut.

Tabel 4 : Sumber Mempelajari Agama bagi Muslim

\begin{tabular}{|c|l|r|r|}
\hline Huruf & \multicolumn{1}{|c|}{ Sumber Belajar Agama } & Jumlah Jawaban & \multicolumn{1}{c|}{$\%$} \\
\hline A & Keluarga, orang tua & 70 & $49 \%$ \\
\hline B & Sekolah, guru & 88 & $61 \%$ \\
\hline C & Madrasah sore, guru ngaji & 50 & $35 \%$ \\
\hline D & Pondok pesantren & 9 & $6 \%$ \\
\hline E & Pengajian-pengajian & 84 & $59 \%$ \\
\hline F & Televisi, radio, internet/komputer & 65 & $45 \%$ \\
\hline G & Buku, koran, majalah & 77 & $54 \%$ \\
\hline H & Dan lain-lain & 2 & $1 \%$ \\
\hline
\end{tabular}


Mereka mempelajari agama Islam tidak hanya dari satu sumber saja tetapi bisa dari dua, tiga atau banyak sumber. Mereka sepakat bahwa sekolah (guru) merupakan sumber belajar yang terbesar (61 $\%$ ), baru kemudian pengajian-pengajian (59\%), dari buku, koran, majalah (54 \%), dan dari keluarga, orang tua (49\%).

Hampir semua responden (125 orang, $87 \%$ ) tidak mengenyam pendidikan agama di pesantren dan hanya 47 orang (33\%) yang mengaku sering mengikuti pengajian-pengajian. Sejumlah besar mereka (109 orang, $76 \%$ ) hanya sedikit memahami isi al-Quran, walaupun kebanyakan mereka (99 orang, 69 \%) mengaku bisa membaca al-Quran.

\section{b. Pelaksanaan Shalat}

Salah satu dari lima rukun Islam adalah shalat, yaitu urutan rukun yang kedua. Hal ini berarti bahwa shalat merupakan kewajiban orang Islam (muslim). Mereka harus mengerjakannya sebanyak 17 reka'at dalam lima waktu, yaitu shubuh dhuhur, ashar, maghrib, dan isya. Namun demikian, banyak kaum muslimin yang tidak mengerjakan shalat atau mengerjakannya hanya sebagian. Alasan mereka tidak mengerjakan shalat adalah bermacam alasan. Berbagai alasan yang dikemukakan oleh para responden yang berjumlah 143 orang dapat dilihat pada tabel berikut. Dalam hal ini setiap responden bisa menyebutkan lebih dari satu alasan.

Tabel 5 : Alasan Muslim Tidak Menjalankan Shalat

\begin{tabular}{|c|l|r|r|}
\hline Huruf & \multicolumn{1}{|c|}{ A I a s a n } & \multicolumn{1}{c|}{$\begin{array}{c}\text { Jumlah } \\
\text { Jawaban }\end{array}$} & \multicolumn{1}{c|}{$\%$} \\
\hline a & Malas & 83 & $58 \%$ \\
\hline b & Lelah sehabis bekerja & 26 & $18 \%$ \\
\hline c & Kesibukan lain & 59 & $41 \%$ \\
\hline d & Tidak berminat & 18 & $13 \%$ \\
\hline e & Tidak mendatangkan uang & 6 & $4 \%$ \\
\hline f & Alasan lain & 19 & $13,3 \%$ \\
\hline
\end{tabular}

Data tersebut menyatakan bahwa kebanyakan muslim tidak mengerjakan shalat karena alasan malas (58 \%), sedangkan alasan yang paling sedikit disampaikan adalah tidak mendatangkan uang atau tidak produktif (4\%). Walaupun demikian, hampir semua responden (133 orang, $93 \%$ ) berpendapat bahwa shalat itu sangat bermanfaat, seperti memperoleh ketenangan, dilatih hidup bersih, dan dilatih disiplin.

Kebanyakan responden (112 orang, $78 \%$ ) mengaku selalu shalat lima waktu, sedang sisanya (22\%) jarang atau tidak sama sekali. Selain itu, kebanyakan mereka (119 orang, $83 \%$ ) mengaku 
hafal bacaan shalat, sedangkan $8 \%$ hafal sebagian besar, dan $9 \%$ hafal sebagian kecil. Kendatipun kebanyakan hafal bacaan shalat, mereka yang memahami seluruh isi bacaan shalat berjumlah 57 orang (40\%), sedang $32 \%$ memahami sebagian besar, dan sisanya yang 28 $\%$ memahami sedikit bahkan tidak paham.

\section{c. Pelaksanaan Puasa}

Puasa, khususnya pada bulan Ramadhan, juga menjadi kewajiban orang, Islam, tetapi ada juga dari mereka (responden 143 orang) tidak berpuasa pada bulan Ramadhan. Mereka berpendapat bahwa orang yang tidak berpuasa karena dengan alasan-alasan tertentu, yang tercantum dalam tabel berikut. Dalam hal ini setiap responden bisa menyebutkan lebih dari satu alasan.

Tabel 6 : Alasan Muslim Tidak Menjalankan Puasa

\begin{tabular}{|c|l|r|r|}
\hline Huruf & \multicolumn{1}{|c|}{ A I a s a n } & \multicolumn{1}{c|}{$\begin{array}{c}\text { Jumlah } \\
\text { Jawaban }\end{array}$} & \multicolumn{1}{c|}{$\%$} \\
\hline a & Malas & 73 & $51 \%$ \\
\hline b & Bekerja berat & 90 & $63 \%$ \\
\hline c & Bikin lemas, lapar dan haus & 27 & $19 \%$ \\
\hline d & Tidak berminat & 16 & $11 \%$ \\
\hline e & Tidak mendatangkan uang & 5 & $3 \%$ \\
\hline f & Alasan lain & 20 & $14 \%$ \\
\hline
\end{tabular}

Dari tabel tersebut diketahui bahwa menurut responden, orang yang tidak berpuasa mayoritas karena bekerja berat (63\%), menyusul alasan berikutnya adalah malas (51\%), bikin lemas, lapar, haus (19 $\%$ ), dan tidak berminat (11\%), sedangkan alasan lain $14 \%$ seperti sedang menstruasi, sedang menyususi, usia lanjut, pengetahuan agama kurang, atau belum percaya penuh bahwa puasa itu wajib. Walaupun demikian, hampir semua responden (135 orang, $94 \%$ ) berpendapat bahwa berpuasa itu sangat bermanfaat, seperti memperoleh kesehatan, solidaritas sosial dengan fakir miskin, dan dilatih disiplin. Hampir semua responden (127 orang, $89 \%$ ) mengaku berpuasa ramadhan, sedang sisanya jarang atau kadang berpuasa dan kadang tidak.

\section{d. Pembayaran Zakat}

Sebagian besar responden (88 orang, $61 \%$ ) mengaku selalu membayar zakat, sedangkan $28 \%$ mengaku hanya membayar zakat fitrah saja dan zakat mal tidak dibayar karena alasan tertentu, dan sisanya yang $11 \%$ kadang membayar kadang tidak. Walaupun zakat harus ditunaikan oleh orang yang mampu (kaya), karena ada syarat 
tertentu, masih ada sebagian dari mereka yang tidak menunaikannya. Hal ini menurut mereka karena berbagai alasan, sebagaimana tertera pada tabel berikut. Dalam hal ini setiap responden bisa menyebutkan lebih dari satu alasan.

Tabel 7 : Alasan Muslim Tidak Membayar Zakat

\begin{tabular}{|c|l|r|r|}
\hline Huruf & \multicolumn{1}{|c|}{ A I a s a n } & $\begin{array}{c}\text { Jumlah } \\
\text { Jawaban }\end{array}$ & \multicolumn{1}{c|}{$\%$} \\
\hline a & Kikir / Pelit & 62 & $43 \%$ \\
\hline b & Sangat mencintai harta / uang & 32 & $22 \%$ \\
\hline c & Mengurangi harta / uang & 14 & $10 \%$ \\
\hline d & Tidak berminat & 17 & $12 \%$ \\
\hline e & Hartanya tidak sampai nisab & 58 & $40 \%$ \\
\hline f & Alasan lain & 16 & $11 \%$ \\
\hline
\end{tabular}

Tabel tersebut menunjukkan bahwa kebanyakan alasan tidak menunaikan zakat adalah karena kikir / pelit (43\%), sedangkan alasan yang terkecil adalah karena merasa uang dan hartanya berkurang (10\%). Alasan lain yang cukup besar adalah karena hartanya tidak mencapai nisab (batas jumlah harta yang disyaratkan dalam zakat). Hampir semua responden (132 orang, $92 \%$ ) meyakini bahwa zakat dapat memberi manfaat yang banyak seperti mensucikan harta dari hak orang lain, solidaritas sosial dengan fakir miskin, memupuk kerukunan dan persatuan.

\section{e. Busana Islami}

Busana Islami yang diwajibkan dalam agama Islam adalah busana yang menutup aurat, bersih, dan menunjukkan kesopanan serta keindahan. Hal ini termasuk baju panjang dan berkerudung bagi perempuan. Responden yang mengaku selalu menggunakan busana islami terutama ketika di luar rumah berjumlah 86 orang (60\%), sedang sisanya $40 \%$ kadang-kadang memakai bahkan tidak memakainya. Mereka yang tidak memakai busana Islami, menurut responden, mempunyai berbagai alasan, sebagaimana pada tabel berikut.

Tabel 8 : Alasan Muslim Tidak Berbusana Islami

\begin{tabular}{|c|l|r|r|}
\hline Huruf & \multicolumn{1}{|c|}{ A I a s a n } & $\begin{array}{c}\text { Jumlah } \\
\text { Jawaban }\end{array}$ & \multicolumn{1}{c|}{$\%$} \\
\hline a & Belum siap mental & 99 & $69 \%$ \\
\hline b & Mengikuti arus jaman & 69 & $48 \%$ \\
\hline c & Tidak cukup uang untuk beli baju & 10 & $7 \%$ \\
\hline d & Tidak didukung keluarga & 21 & $14 \%$ \\
\hline e & Malu diolok-olok teman / saudara & 16 & $11 \%$ \\
\hline f & Alasan lain & 9 & $6 \%$ \\
\hline
\end{tabular}


Tabel tersebut menunjukkan bahwa kebanyakan alasan tidak memakai busana islami adalah karena belum siap mental (69\%), sedangkan alasan yang terkecil adalah karena merasa uangnya tidak cukup untuk membeli busana islami atau alasan lain (6-7 \%). Alasan mengikuti arus jaman juga diakui oleh $48 \%$ responden.

\section{f. Melakukan Kemaksiatan}

Kebanyakan responden (86 orang, $60 \%$ ) mengaku tidak melakukan kemaksiatan (keburukan) dan hanya $2 \%$ dari mereka yang mengaku sering melakukannya, sedangkan sisanya (38\%) mengaku kadang bermaksiat kadang tidak. Berbagai jenis kemaksiatan yang dilakukan dapat dilihat pada Tabel 9. Dalam tabel tersebut dinyatakan bahwa menurut responden (58\%), buruk sangka, benci, dengki, iri dan dendam adalah kemaksiatan yang paling sering dilakukan. $47 \%$ dari mereka berpendapat bahwa perjudian merupakan kemaksiatan yang banyak dilakukan. Responden mengakui bahwa membunuh ( $17 \%$ responden), mencuri dan merampok (22\% responden) adalah termasuk kemaksiatan yang jarang dilakukan.

Tabel 9 : Jenis Kemaksiatan yang Dilakukan Muslim

\begin{tabular}{|c|l|r|r|}
\hline Huruf & \multicolumn{1}{|c|}{ Jenis Kemaksiatan } & \multicolumn{1}{c|}{$\begin{array}{c}\text { Jumlah } \\
\text { Jawaban }\end{array}$} & \multicolumn{1}{c|}{$\%$} \\
\hline A & Perjudian & 67 & $47 \%$ \\
\hline B & Minuman keras & 50 & $35 \%$ \\
\hline C & Berzina, prostitusi & 39 & $27 \%$ \\
\hline D & Mencuri, merampok & 32 & $22 \%$ \\
\hline E & Membunuh & 24 & $17 \%$ \\
\hline F & Sogok, suap, korupsi & 48 & $33 \%$ \\
\hline G & Menipu, mengelabui & 51 & $35 \%$ \\
\hline h & Benci, iri, dengki, dendam & 84 & $58 \%$ \\
\hline i & Buruk sangka, julukan buruk & 84 & $58 \%$ \\
\hline j & Dan lain-lain & 8 & $5 \%$ \\
\hline
\end{tabular}

Adapun alasan seseorang melakukan kemaksiatan, menurut responden, adalah sebagai berikut (Tabel 10) (Dalam hal ini setiap responden bisa menyebutkan lebih dari satu alasan.) :

Tabel 10 : Alasan Muslim Melakukan Maksiat

\begin{tabular}{|c|l|r|r|}
\hline Huruf & \multicolumn{1}{|c|}{ A I a s a n } & $\begin{array}{c}\text { Jumlah } \\
\text { Jawaban }\end{array}$ & \multicolumn{1}{c|}{$\%$} \\
\hline a & Kurang memahami agama & 107 & $75 \%$ \\
\hline b & Rakus, serakah & 12 & $8 \%$ \\
\hline c & Tidak bisa mengendalikan nafsu & 84 & $58 \%$ \\
\hline d & Pengaruh teman atau lingkungan & 49 & $34 \%$ \\
\hline e & Tuntutan (kebutuhan) ekonomi & 31 & $21 \%$ \\
\hline
\end{tabular}


Alasan bermaksiat yang paling besar adalah karena kurang memahami agama (75\%). Hal ini bisa dimaklumi, karena data lain menunjukkan bahwa hampir semua responden (125 orang, $87 \%$ ) tidak mengenyam pendidikan agama di pesantren dan hanya 47 orang (33 $\%$ ) yang mengaku sering mengikuti pengajian-pengajian. Pendidikan agama semacam ini mengakibatkan sejumlah besar mereka (109 orang, $76 \%$ ) hanya sedikit memahami isi al-Quran, walaupun kebanyakan mereka (99 orang, 69 \%) mengaku bisa membaca al-Quran.

\section{Analisis tentang Penyimpangan terhadap Agama Islam}

\section{a. Faktor Penyimpangan Pengetahuan tentang Agama Islam}

Dalam pandangan Islam mencari ilmu adalah wajib, baik bagi muslimin maupun muslimat. Dalam hadits riwayat Bukhori Muslim dikatakan, "mencari ilmu itu fardhu (wajib) bagi setiap muslim laki-laki maupun perempuan". Ilmu yang wajib dituntut terutama adalah ilmu agama, yaitu ilmu tentang pokok-pokok pengetahuan Islam seperti rukun Islam, rukun iman, kemampuan membaca dan memahami al-Quran dan al-Hadits, dan sebagainya. Sedangkan ilmuilmu lain sifatnya hanya sunnah. Menurut Imam Ghazali, ilmu agama itu bersifat fardhu ain (wajib pribadi), sedangkan ilmu lainnya bersifat fardhu kifayah (wajib kelompok). Dengan demikian secara ideal seorang muslim harus benar-benar memahami ajaran agamanya.

Data penelitian menunjukkan bahwa hampir semua responden (125 orang, $87 \%$ ) tidak mengenyam pendidikan agama di pesantren dan hanya 47 orang (33\%) yang mengaku sering mengikuti pengajianpengajian. Pendidikan agama semacam ini mengakibatkan sejumlah besar mereka (109 orang, $76 \%$ ) hanya sedikit memahami isi alQuran, walaupun kebanyakan mereka (99 orang, 69\%) mengaku bisa membaca al-Quran.

Data ini menunjukkan bahwa ternyata kebanyakan orang Islam tidak memahami al-Quran, walaupun sebagian bisa membacanya, dan juga tidak memahami agamanya dengan baik. Hal ini disebabkan oleh usaha mereka yang belum maksimal dalam belajar agama, mereka yang hanya mengandalkan pelajaran agama sewaktu belajar di sekolah, dan mereka sedikit belajar agama dari pengajian-pengajian maupun lewat televisi dan radio.

Hal itu didukung dengan data lain tentang sumber belajar agama Islam. Data yang dimaksud menyatakan, responden sepakat bahwa sekolah (guru) merupakan sumber belajar yang terbesar (61 $\%$ ), baru kemudian pengajian-pengajian (59\%), dari buku, koran, 
majalah (54\%), dan dari keluarga, orang tua (49\%). Dengan demikian faktor lingkungan yang berupa keluarga, fasilitas televisi, radio, buku, koran, dan forum-forum pengajian belum sepenuhnya dimanfaatkan untuk mempelajari agama Islam.

Solusi yang perlu diberikan untuk mengatasi problem ini adalah terus belajar dan belajar tentang agama Islam, melalui berbagai cara dan sarana, seperti belajar di sekolah, di rumah, di masjid-masjid, melalui pengajian-pengajian, televisi, radio, membaca buku, koran, majalah, dan sebagainya. Belajar dari pengalaman sendiri atau orang lain adalah juga metode yang baik untuk belajar agama.

\section{b. Faktor Penyimpangan Sholat}

Allah memerintah orang Islam untuk menegakkan shalat. Menegakkan sholat, yaitu melaksanakan sholat yang dimulai dengan takbirotul-ikhrom dan diakhiri dengan salam dengan syarat dan rukun tertentu, kemudian mengamalkan ajaran shalat dalam kehidupan seharihari, seperti ajaran kebersihan, kedisiplinan, kerukunan, persatuan, dan sebagainya. Orang yang menegakkan sholat hendaknya memahami dan mengamalkan bacaan sholat maupun ajaran-ajaran dalam sholat.

Data penelitian menunjukkan bahwa kebanyakan responden (112 orang, $78 \%$ ) mengaku selalu shalat lima waktu, sedang sisanya (22\%) jarang atau tidak sama sekali. Selain itu, kebanyakan mereka (119 orang, $83 \%$ ) mengaku hafal bacaan shalat, sedangkan $8 \%$ hafal sebagian besar, dan $9 \%$ hafal sebagian kecil. Kendatipun kebanyakan hafal bacaan shalat, mereka yang memahami seluruh isi bacaan sholat berjumlah 57 orang (40\%), sedang $32 \%$ memahami sebagian besar, dan sisanya yang $28 \%$ memahami sedikit bahkan tidak paham. Orang shalat yang tidak memahami isi bacaan, walaupun hafal bacaannya, merupakan bentuk penyimpangan dalam shalat.

Data yang menyatakan bahwa $22 \%$ responden mengaku jarang atau tidak shalat sama sekali menunjukkan bahwa masih ada penyimpangan orang Islam, yaitu meninggalkan shalat. Alasan mereka tidak shalat bermacam-macam. Sebagaimana data penelitian, bahwa kebanyakan muslim tidak mengerjakan sholat karena alasan malas (diakui oleh $58 \%$ responden), lalu kesibukan selain shalat (44\%), lelah sehabis kerja (18\%), tidak berinat (13\%) sedangkan alasan yang paling sedikit disampaikan adalah tidak mendatangkan uang atau tidak produktif (4 \%). Bahkan S misalnya, seorang sopir angkutan kota Semarang lulusan SD, ketika ditanya apakah dia melaksanakan shalat, dia menjawab, "ndak shalat, karena ndak bisa, tapi ada semangat untuk shalat, sewaktu ada yang ngajak juga mau”. 
Data tersebut di atas menunjukkan penyimpangan dalam hal shalat, artinya seorang muslim seharusnya melaksanakan dan menegakkan rukun Islam kedua itu tetapi masih banyak yang mengabaikannya. Penyimpangan tersebut akan bertambah lagi ketika dia tidak memahami bacaan shalat. Hal ini berkaitan dengan faktor pengetahuan agama yang kurang, khususnya tentang shalat. Karena usaha belajar agama yang kurang, mereka tidak memahami agama dengan baik, sehingga tidak mengamalkan ajaran agama seperti shalat. Itulah yang disebutkan seorang informan (S) di atas.

Faktor kesadaran yang rendah tentang kewajiban sebagai seorang muslim juga memunculkan penyimpangan tersebut di atas. Para responden (58\%) menyatakan bahwa alasan orang Islam tidak shalat karena malas dan alasan karena kesibukan dunia diakui oleh 44 $\%$ responden.

Solusi dari permasalahan (penyimpangan) ini adalah bahwa seorang muslim harus selalu meningkatkan pengetahuan agamanya dan terus meningkatkan kesadaran sebagai seorang muslim dengan cara berusaha mengamalkan ajaran Islam dalam kehidupan seharihari, dan juga selalu berdoa agar tetap teguh (istiqomah) dalam berislam.

\section{c. Faktor Penyimpangan Puasa}

Melaksanakan puasa (Ramadhan), yaitu menahan diri dari makan, minum, merokok, hubungan suami istri, dan hal-hal yang membatalkan puasa mulai dari terbit fajar (shubuh) sampai terbenamnya matahari (maghrib) dengan syarat dan rukun tertentu.

Berkaitan dengan puasa, data penelitian menunjukkan bahwa hampir semua responden (127 orang, $89 \%$ ) mengaku berpuasa ramadhan, sedang sisanya $(11 \%)$ jarang atau kadang berpuasa kadang tidak. Menurut responden, orang yang tidak berpuasa mayoritas karena bekerja berat ( diakui oleh $63 \%$ responden), menyusul alasan berikutnya adalah malas ( $51 \%$ ), bikin lemas, lapar, haus ( $19 \%$ ), dan tidak berminat ( $11 \%$ ), sedangkan alasan lain $14 \%$ seperti sedang menstruasi, sedang menyususi, usia lanjut, pengetahuan agama kurang, atau belum percaya penuh bahwa puasa itu wajib.

Walaupun demikian, hampir semua responden (135 orang, $94 \%$ ) berpendapat bahwa berpuasa itu sangat bermanfaat, seperti memperoleh kesehatan, solidaritas sosial dengan fakir miskin, dan dilatih disiplin, sedangkan sisanya $6 \%$ responden berpendapat bahwa puasa tidak ada manfaatnya. 
Sejumlah $11 \%$ responden mengaku tidak atau jarang sekali berpuasa menunjukkan penyimpangan seorang muslim yang seharusnya berpuasa Ramadhan tetapi tidak berpuasa. Problem ini tidak lepas dengan faktor pengetahuan agama dan kesadaran beragama yang rendah, selain faktor kenyataan penyebab tidak berpuasa yaitu lapar dan haus serta lemas ketika berpuasa, sebagaimana diakui oleh $19 \%$ responden. Hal ini dapat diketahui dengan pernyataan S dan S sebagaimana tersebut di atas.

Solusi dari permasalahan (penyimpangan) ini adalah bahwa seorang muslim harus selalu meningkatkan pengetahuan agamanya dan terus meningkatkan kesadaran sebagai seorang muslim dengan cara berusaha mengamalkan ajaran Islam dalam kehidupan sehari-hari, khususnya puasa, dan juga selalu berdoa agar tetap teguh (istiqomah) dalam berislam. Selain itu, untuk persiapan puasa, usaha menjaga kesehatan dan makan serta minum yang bergizi juga merupakan solusi.

\section{d. Faktor Penyimpangan Zakat}

Membayar zakat, yaitu memberikan sejumlah harta kepada orang yang berhak menerima seperti fakir miskin, yatim piatu, orang yang terjerat hutang, dan sebagainya, dengan syarat dan rukun tertentu, serta bagi orang yang mampu. Data penelitian menunjukkan bahwa Sebagian besar responden ( 88 orang, $61 \%$ ) mengaku selalu membayar zakat, sedangkan $28 \%$ mengaku hanya membayar zakat fitrah saja dan zakat mal tidak dibayar karena alasan tertentu, dan sisanya yang $11 \%$ kadang membayar kadang tidak.

Kebanyakan alasan tidak menunaikan zakat adalah karena kikir / pelit (diakui oleh $43 \%$ responden), sedangkan alasan yang terkecil adalah karena merasa uang dan hartanya berkurang (10\%). Alasan lain yang cukup besar adalah karena hartanya tidak mencapai nisab (batas jumlah harta yang disyaratkan dalam zakat), yaitu 40 $\%$ responden, dan juga alasan karena sangat cintanya pada harta (22 \%). Hampir semua responden (132 orang, $92 \%$ ) meyakini bahwa zakat dapat memberi manfaat yang banyak seperti mensucikan harta dari hak orang lain, solidaritas sosial dengan fakir miskin, memupuk kerukunan dan persatuan.

Data tersebut menunjukkan bahwa penyimpangan seorang muslim masih terjadi yaitu tidak membayar zakat dengan alasan terutama karena kikir / pelit. Alasan yang lain adalah karena hartanya belum sampai satu nisab dalam jangka waktu setahun. Faktor penyimpangan ini adalah faktor pengetahuan tentang zakat 
yang kurang dan juga faktor kesadaran bahwa seorang muslim kaya harus mengeluarkan zakat. Faktor tersebut lebih diperparah dengan paradigma materialistik yang mendominasi kehidupan manusia.

Solusi yang perlu diberikan dalam masalah ini adalah, khususnya bagi seorang muslim kaya, hendaknya meningkatkan pengetahuan tentang agama Islam, khususnya zakat, dan perlu meningkatkan kesadaran bahwa harta benda hanyalah amanah (barang titipan) Allah, hanya Dia sebagai pemilik segalanya. Selain itu, pengetahuan dan penghayatan tentang nasib menyedihkan si fakir miskin harus benar-benar diperoleh orang-orang kaya.

\section{e. Faktor Penyimpangan Busana Islami}

Agama Islam mewajibkan pemeluknya baik laki-laki maupun perempuan untuk berbusana islami, yaitu berbusana menurut tuntutan agama Islam dengan prinsip menutup aurat (bagian tubuh yang harus tertutup), kesopanan, dan keindahan. Aurat laki-laki adalah antara pusar dan lutut, tetapi busana islami untuk laki-laki harus tetap sopan. Sedangkan aurat perempuan adalah seluruh anggota tubuh kecuali wajah dan telapak tangan, sehingga seorang wanita muslimah harus memakai baju panjang, bawahan panjang, dan berkerudung jika keluar rumah.

Dalam kenyataan penyimpangan terhadap busana islami terutama oleh orang-orang Islam masih terjadi. Data penelitian menunjukkan para responden yang mengaku selalu menggunakan busana islami terutama ketika di luar rumah berjumlah 86 orang (60\%), sedang sisanya $40 \%$ kadang-kadang memakai bahkan tidak memakainya. Mereka yang tidak memakai busana islami, menurut responden, mempunyai berbagai alasan. Kebanyakan alasan tidak memakai busana islami adalah karena belum siap mental (69\%), sedangkan alasan yang terkecil adalah karena merasa uangnya tidak cukup untuk membeli busana islami atau alasan lain (6-7 \%). Alasan mengikuti arus jaman juga diakui oleh $48 \%$ responden.

Dari data tersebut dapat ditegaskan bahwa faktor penyimpangan busana islami adalah faktor pengetahuan dan kesadaran yang rendah tentang busana islami. Solusi dari permasalahan busana islami ini adalah memahami betul tentang agama Islam, khususnya busana islami, kemudian mengamalkannya. Dukungan, nasehat, saran dari keluarga atau teman sangat berarti untuk mendukung pengamalan busana islami. Mereka yang sudah berbusana islami juga dapat memberi motivasi bagi yang belum. 


\section{f. Faktor Melakukan Kemaksiatan}

Agama Islam melarang berbagai kemaksiatan seperti berjudi, prostitusi (berzina), korupsi, mabuk-mabukkan, mencuri, merampok, membunuh, dan sebagainya. Larangan ini berlaku untuk semua orang, termasuk muslimin dan muslimat. Namun dalam kenyataan, berbagai kemaksiatan tersebut masih terlihat dalam kehidupan sehari-hari.

Data penelitian menunjukkan bahwa masih ada $2 \%$ dari responden yang mengaku sering melakukan kemaksiatan dan $38 \%$ responden mengaku kadang bermaksiat kadang tidak. Berbagai jenis kemaksiatan yang dilakukan dapat dilihat pada Tabel 9. Dalam tabel tersebut dinyatakan bahwa menurut responden (58 \%), buruk sangka, benci, dengki, iri dan dendam adalah kemaksiatan yang paling sering dilakukan. $47 \%$ dari mereka berpendapat bahwa perjudian merupakan kemaksiatan yang banyak dilakukan. Responden mengakui bahwa membunuh (17\% responden), mencuri dan merampok $(22 \%$ responden) adalah termasuk kemaksiatan yang jarang dilakukan.

Kemaksiatan yang dilakukan oleh orang Islam, baik besar maupun kecil, merupakan bentuk penyimpangan sebagai seorang muslim. Apapun alasan kemaksiatan tetap menunjukkan penyimpangan. Data tersebut di atas menyatakan penyimpangan tersebut. Hal ini memang tidak lepas dari faktor kepribadian, faktor pengetahuan, dan faktor lingkungan.

Oleh karena itu, solusi yang diberikan untuk mengatasi masalah itu adalah meningkatkan pengetahuan dan pengamalan ajaran agama, lalu berusaha bergaul dengan baik untuk mencari lingkungan yang baik. Dalam hal ini, saran dan nasehat dari anggota keluarga, tetangga, dan teman akan sangat bermanfaat. Solusi masalah kemaksiatan ini juga harus didukung dengan ketegasan pemerintah untuk membasmi kemaksiatan seperti perjudian, prostitusi, mabuk-mabukkan, korupsi, dan sebagainya.

\section{G. KESIMPULAN}

Dari rumusan masalah, pengungkapan data penelitian, dan analisis data tersebut, penelitian ini dapat disimpulkan sebagai berikut :

1. Penyimpangan-penyimpangan yang muncul pada diri seorang muslim, antara lain, adalah tidak memahami agama Islam, tidak shalat, tidak puasa, tidak membayar zakat, tidak berbusana Islami.

2. Faktor-faktor yang berkaitan dengan berbagai penyimpangan agama adalah faktor kepribadian (malas, tidak berminat, tidak mengamalkan), faktor ekonomi (kemiskinan, sibuk bekerja, orientasi pada uang dan harta), dan faktor keilmuan (tidak belajar, tidak mengetahui, dan tidak 
paham), dan faktor lingkungan (hubungan dengan keluarga, tetangga, teman, dan masyarakat umumnya).

3. Solusi untuk mengatasi penyimpangan-penyimpangan tersebut, antara lain, dengan :

a. Peningkatan ilmu agama Islam

b. Pengamalan ajaran agama Islam

c. Pergaulan dan penciptaan lingkungan yang baik

d. Pencarian titik tengah jika ada konflik antara agama dan budaya

4. Pola penyimpangan tersebut dapat dijelaskan dan digambarkan berikut :

Dalam hal ini penyimpangan-penyimpangan berkaitan dengan (dipengaruhi oleh) faktor pengetahuan, kepribadian, lingkungan, dan ekonomi. Faktor pengetahuan dan kepribadian saling berkaitan. Faktor pengetahuan dan lingkungan saling berkaitan. Faktor kepribadian berkaitan dengan faktor lingkungan.

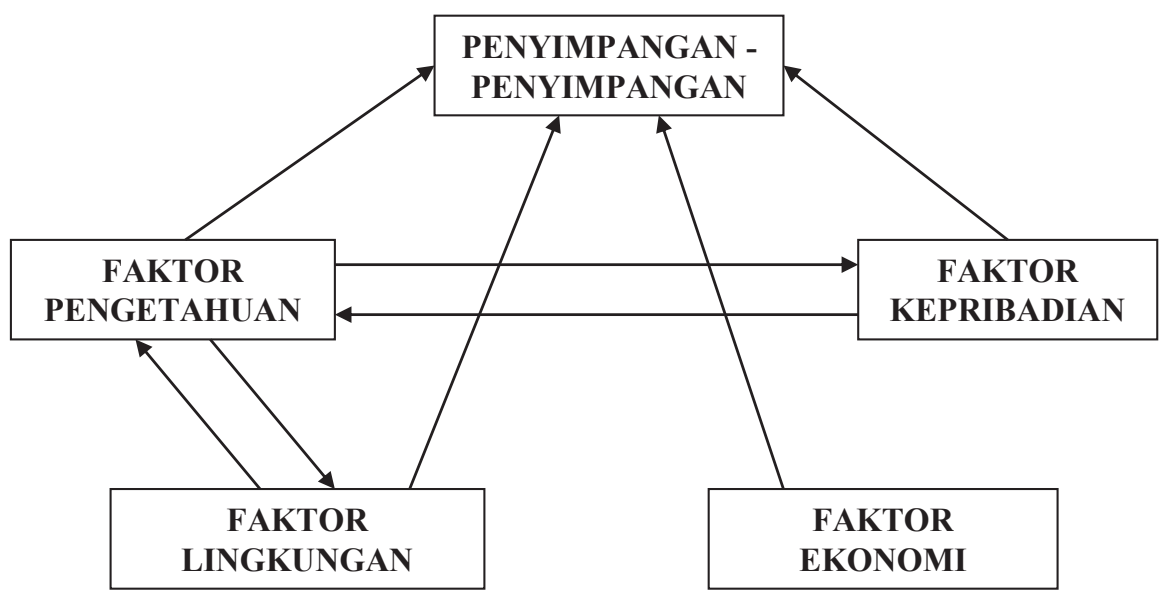




\section{DAFTAR PUSTAKA}

Attfield, A Theory of Value and Obligation, Croom Helm, Mew York, 1987

Bakker, JWM., Filsafat Kebudayaan : Sebuah Pengantar, cetakan ke-12, Kanisius, Yogyakarta, 2001

Bintoro, Asri, Seri Kejawen 2002, Jilid 1, Agra Institute, Jakarta, 2002

Burhanuddin Salam, Filsafat manusia: Antropologi Metafisika, Bina Aksara, Jakarta, 1988

Coser, Lewis.A., the Functions of Social Conflict, Free Press of Glencoe, London, 1956

------- Continuities in the Study of Social Conflict, Free Press, New York, 1967

Dahrendorf, Ralf, Class and Class Conflict in Industrial Society, Stanford University Press, Stanford California, 1959

Darban, Ahmad Adaby, Agama dan Transformasi Kebudayaan, makalah disampaikan pada Internship Dosen-dosen Ilmu Budaya Dasar seIndonesia tanggal 18 - 27 Agustus 1998 di Yogyakarta

Encyclopedia of Americana - The, Volume 9, 30 th edition, Grolier Incorporated, Danbury Connecticut, 2000

Faisal Ismail, Paradigma Kebudayaan Islam: Studi Kritis dan Refleksi Historis, Titian Ilahi Press, Yogyakarta, 1996

Feisal, Jusuf Amir, Reorientasi Pendidikan Islam, Gema Insani Press, Jakarta, 1995

Hussain, Syekh Syaukat, Hak Asasi Manusia dalam Islam, Abdul Rochim (penerjemah), Gema Insani Press, Jakarta, 1996

Kamali, Mohammad Hashim, Kebebasan Berpendapat dalam Islam, Eva Y. Nukman \& Fathiyah Basri (penerjemah), Mizan, Bandung, 1996

Kedaulatan Rakyat, 30 Juli 2003

Kompas, 17 Maret 2002

Lemos, N.M., "Value Theory" dalam the Cambridge Dictionary of Philosophy, editor by Robert Audi, Cambridge University Press, Cambridge, 1996

Mangunhardjana, A., Isme-Isme dalam Etika dari A sampai Z, Kanisius, Yogyakarta, 1997

Mitchell, D. Duncan (editor), a New Dictionary of the Social Sciences, Aldine Publishing Company, New York, 1979 
Muhammad Chabib Thoha, Teori dan Praktek Pendidikan Nilai dalam alFikri (Majalah Ilmiah Fakultas Tarbiyah UNISSULA Semarang) edisi No. 17/Desember/Th.V/1995

Muhammad Muhtar Arifin Sholeh, dkk., Ilmu Budaya Dasar (Kajian dengan Nuansa Islami), Sultan Agung University Press, Semarang, 2000

Muhammad Muhtar Arifin Sholeh, Akhlaq Pribadi: Etika Berpikir menurut Islam dalam al-Fikri (Majalah Ilmiah Fakultas Tarbiyah UNISSULA Semarang) edisi No. 20/September/Th.VI/1996

Nahlawi-an, Abdurrahman, Pendidikan Islam di Rumah, Sekolah, dan Masyarakat, Shihabuddin (penerjemah), Gema Insani Press, jakarta, 1995

Notowidagdo, Rohiman, Ilmu Budaya Dasar Berdasarkan Al-Quran dan AlHadits, cet. ke-2, Rajawali Press, Jakarta, 1997

Safri Sairin, Etika sebagai Manifestasi Budaya, makalah disampaikan pada Internship Dosen-dosen Ilmu Budaya Dasar se-Indonesia tanggal 18 27 Agustus 1998 di Yogyakarta

Sarjuni, Pendidikan Moral dalam Perspektif Global dalam al-Fikri (Majalah Ilmiah Fakultas Tarbiyah UNISSULA Semarang) edisi No. 20/ September/Th.VI/1996

Shiddiqie-ash, Jimly, dkk. (editor), Sumber Daya Manusia untuk Indonesia Masa Depan, PT Cita Putra Bangsa (Jakarta) dan Mizan (Bandung), 1996

Soekanto, Soerjono \& Ratih Lestarini, Fungsionalisme dan Teori Konflik dalam Perkembangan Sosiologi, Sinar Grafika, Jakarta, 1988

Sri Soeprapto, Aspek Ontologis Hakikat Manusia, makalah disampaikan pada Internship Dosen-dosen Ilmu Budaya Dasar se-Indonesia tanggal 18 27 Agustus 1998 di Yogyakarta

Suara Merdeka, 22 Juli 2003

Suseno, Franz Magnis, Etika Jawa: sebuah analisis Falsafi tentang Kebijaksanaan hidup Jawa, Gramedia, Jakarta, 1996

Suyanto, Wayang Malangan, Citra Etnika Surakarta, Surakarta, 2002

Tap MPR No.II/MPR/1998 tentang Garis-Garis Besar Haluan Negara (GBHN)

Teuku Jacob, Hakekat Manusia: Aspek Biologisnya, makalah disampaikan pada Internship Dosen-dosen Ilmu Budaya Dasar se-Indonesia tanggal 18 - 27 Agustus 1998 di Yogyakarta 
Tirtarahardja, Umar \& La Sula, Pengantar Pendidikan, Rineka Cipta, 2000

Qardawi-al, Yusuf, as-Sunnah sebagai Sumber Iptek dan Peradaban, Setiawan Budi Utomo (penerjemah), Pustaka al-Kautsar, Jakarta, 1998

Yunahar Ilyas, Kuliah Akhlaq, cetakan IV, Lembaga Pengkajian dan Pengamalan Islam (LPPI) Universitas Muhammadiyah Yogyakarta (UMY), Yogyakarta, 2001

Zainuddin Bukhori, Islamisasi Wayang Kulit dalam al-Fikri (Majalah Ilmiah Fakultas Tarbiyah UNISSULA Semarang) edisi No.6/Maret/Th.III/1993

Zarkasi Effendi, Nilai Islam dalam Pewayangan, Depag, Jakarta, 1977 